\title{
Implemetasi Kebijakan Ketertiban, Kebersihan, Keindahan (K-3) di Kecamatan Subang Kabupaten Subang
}

\author{
Ade Nawawi ${ }^{1}$ \\ Fakultas Ilmu Administrasi Universitas Subang \\ adenawawi15.an@gmail.com \\ Ade Suparman ${ }^{2}$ \\ Fakultas Ilmu Administrasi Universitas Subang \\ suparmanade09@gmail.com
}

\begin{abstract}
Abstrak
Tujuan dilakukannya penelitian ini adalah untuk mengetaui Implementasi Kebijakan Ketertiban, Kebersihan, Keindahan (K-3) di Kecamatan Subang Kabupaten Subang, dengan mengindikatori Implementasi Kebijakan yang mencakup standard an sasaran kebijakan, sumber daya, komunikasi antar badan pelaksana, karakteristik badan pelaksana, lingkungan sosial, ekonomi, dan politik, dan yang terakhir sikap pelaksana.Berdasarkan hasil penelitian, dapat digambarkan bahwa Implementasi Kebijakan Ketertiban, Kebersihan, Keindahan (K-3) di Kecamatan Subang Kabupaten Subang belum berjalan optimal, hal ini dapat dilihat sumber daya yang dimiliki diantaranya masih rendahnya anggaran untuk Program Ketertiban, Kebersihan, Keindahan (K-3) dan masih rendahnya komunikasi aparatur Kecamatan Subang dengan UPTD-UPTD lainnya.
\end{abstract}

Kata kunci : Implementasi Kebijakan, Ketertiban, Kebersihan, Keindahan (K-3)

\section{Abstract}

The purpose of this scripture research is to know the Implementation of Order Policy, Cleanliness, Beauty (K-3) in Subang Sub-District, Subang Regency, by indicating the Policy Implementatiton which includes standards and policy objectives, resources, communication between implementing agencies, implementing agency characteristics, and finally the attitude of the implementer.Based on the results of the study, it can be illustrated that the Implementation of Order Policy, Cleanliness, Beauty (K-3) Program and still the lack of communication between the Subang Sub-District apparatus and other UPTDs.

Keywords : Policy Implementation, Order, Cleanliness, Beauty (K-3). 


\section{Pendahuluan}

Kebijakan publik dapat dipandang sebagai kebijakan yang dipilih pemerintah untuk melakukan suatu tindakan atau tidak melakukan suatu tindakan dalam suatu rangkaian yang saling berkaitan dan masing-masing kebijakan tersebut memiliki tujuan-tujuan tertentu yang hendak dicapai. Agar suatu kebijakan dapat mencapai tujuan yang telah ditetapkan, maka kebijakan tersebut harus diimplementasikan. Tanpa implementasi suatu kebijakan hanyalah sekedar sebuah dokumen yang tidak bermakna dalam kehidupan bermasyarakat. Banyak kebijakan yang baik yang telat dibuat oleh pemerintah, ternyata tidak mempunyai pengaruh apa-apa dalam kehidupan masyarakat karena tidak bisa diimplementasikan dengan baik.

Demikian pula hal nya kebijakan dalam bidang kebersihan yang akan penulis teliti yaitu terdapat pada Peraturan Daerah Kabupaten Subang No 13 tahun 2006 tentang Ketertiban, Kebersihan, Keindahan (K-3) di Kabupaten Subang, karena untuk mencapai masyarakat yang tentram sehat dan sejahtera diperlukan adanya suasana yang tertib, bersih, dan indah. Kebersihan adalah keadaan bebas dari kotoran, termasuk diantaranya debu, sampah, dan bau. Ketertiban merupakan keadaan menjadi lebih tenang, damai, aman, dan sentosa.

Pelaksanaan program Ketertiban, Kebersihan, Keindahan (K-3) yang merujuk kepada Peraturan Daerah di atas diharapkan dapat berimbas pada peningkatan kesehatan masyarakat, lingkungan yang tertib, bersih, dan indah akan mempengaruhi tingkat kesehatan lingkungan masyarakat. Salah satu masalah terbesar dalam Peraturan Daerah tentang Ketertiban, Kebersihan, Keindahan (K-3) yaitu masalah sampah karena sampah merupakan masalah kebersihan yang merupakan konsekuensi kehidupan yang ditimbulkan dari jumlah penduduk. Peningkatan jumlah penduduk berarti peningkatan jumlah timbunan sampah, dan semakin beragam aktivitas berarti semakin beragam jenis sampah yang dihasilkan, salah satu contohnya di Kecamatan Subang.

Kecamatan Subang merupakan salah satu Kecamatan terpadat di Kabupaten Subang dengan luas wilayah 5,896,966 HA, memiliki penduduk sebanyak 176,140 jiwa, dan memiliki jumlah kepala keluarga sebanyak 46,978 kepala keluarga (sumber data: Kecamatan Subang). Di Kecamatan Subang, kesadaran masyarakat dalam melaksanakan Ketertiban, Kebersihan, Keindahan (K-3) dirasa masih kurang, terbukti dari masih adanya sampah di sepanjang jalan dan masih adanya pula pengemis di kecamatan Subang ini. Di Kecamatan Subang, karena sampah merupakan problema kehidupan yang sering menimbulkan masalah dan jumlahnya akan semakin meningkat seiring dengan peningkatan jumlah penduduk. Mengacu kepada Peraturan Daerah tentang Ketertiban, Kebersihan, Keindahan (K-3) yang mengintruksikan di setiap Desa atau Kelurahan memiliki Tempat Penampungan Sementara (TPS) masing-masing.

Kecamatan Subang yang memiliki luas wilayah cukup luas dan jumlah penduduk juga cukup banyak. Menurut Dinas Lingkungan Hidup, perkiraan sampah yang dihasilkan tiap 1 orang yaitu $0,8 \mathrm{Kg}$, bila dikali dengan jumlah penduduk Kecamatan Subang dengan jumlah penduduk yang mencapai 176,140 jiwa maka perhari Kecamatan Subang dapat menghasilkan sampah dengan jumlah 140,912 Kg, 
jika dikalikan sebulan maka Kecamatan Subang menghasilkan sampah sebanyak 4,227,360 Kg. Jadi, dalam setahun Kecamatan Subang dapat menghasilkan 51,432,880 Kg. Dengan sampah yang dihasilkan sebanyak itu seharusnya pemerintah Kecamatan Subang memberikan akses pelayanan publik yang paripurna diantaranya dalam pengelolaan Ketertiban, Kebersihan, Keindahan (K-3) yang optimal dengan sosialisasi yang tepat kepada masyarakat disertai regulasi yang jelas, tegas, dan simpel. Dalam hal ini, peran pemerintah dituntut lebih besar sehingga masyarakat merasakan betul pelayanan publik yang diberikan oleh para pemegang kebijakan.

Berdasarkan data yang diperoleh dari Dinas Kependudukan di Kabupaten Subang seperti pada tabel dibawah ini,

Tabel 1.

Data Sampah Kelurahan

Di Kecamatan Subang bulan Juli tahun 2019

\begin{tabular}{|c|l|c|c|}
\hline NO & $\begin{array}{c}\text { NAMA } \\
\text { KELURAHAN }\end{array}$ & $\begin{array}{c}\text { JUMLAH } \\
\text { PENDUDUK }\end{array}$ & $\begin{array}{c}\text { PERKIRAAN VOLUME SAMPAH } \\
\text { SETAHUN (jumlah penduduk } x \text { 0,8 kg/org/hr } x \\
365 \text { hari) }\end{array}$ \\
\hline a & \multicolumn{1}{c}{ b } & C & d \\
\hline 1 & Cigadung & 25,392 & $7,414,464$ \\
\hline 2 & Sukamelang & 17,474 & $5,102,408$ \\
\hline 3 & Dangdeur & 17,331 & $5,060,652$ \\
\hline 4 & Soklat & 15,093 & $4,407,156$ \\
\hline
\end{tabular}

Sumber data: Dinas Kependudukan bulan Juli Kabupaten Subang

Sedangkan soal ketertiban juga belum maksimal, karena masih adanaya 35 orang yang mengemis di wilayah Kecamatan Subang ini. Untuk program keindahan, jika program kebersihan berjalan maksimal maka akan tercipta Kecamatan Subang yang bersih yang enak dilihat oleh semua orang. Secara Keseluruhan Program Ketertiban, Kebersihan, Keindahan (K-3) di Kecamatan Subang belum terlaksana secara maksimal. Hal ini tentunya menjadi hal yang perlu dibenahi, terutama akan kesadaran masyarakat yang masih banyak membuang sampah sembarangan, supaya terciptanya Kecamatan Subang yang bersih.

Berdasarkan hasil pengamatan penulis, kondisi program Ketertiban, Kebersihan, Keindahan (K-3) khususnya Kebersihan di Kecamatan Subang Kabupaten Subang masih belum maksimal, karena: masih kurangnya anggaran untuk pelaksanaan Ketertiban, Kebersihan, Keindahan (K-3) di Kecamatan Subang Kabupaten Subang; dan masih rendahya komunikasi aparatur Kecamatan Subang dengan UPTD-UPTD lainnya. Sementara menurut pengetahuan penulis regulasinya sudah ada, yaitu Peraturan Daerah Kabupaten Subang Nomor 13 Tahun 2006 tentang Ketertiban, Kebersihan, Keindahan (K-3) di Kabupaten Subang, karena berdasarkan Bab II tentang Ketertiban pasal 4, berisi menggelandang atau mengemis di muka umum, dan Bab III tentang Kebersihan pasal 7, berisi penyelenggaraan kebersihan lingkungan dilaksanakan melalui koordinasi RT/RW melalui kegiatan pewadahan dan atau pemilahan, 
penyapuan dan pengumpulan serta pemindahan sampah dari lingkungan ke Tempat Penampungan Sementara (TPS). Pasal 8, membuang sampah, kotoran atau barang bekas lainnya di saluran, jalan, trotoar, tempat umum, tempat pelayanan umum, dan tempat-tempat lainnya. Pasal 10, pemerintah daerah berkewajiban menumbuhkan dan mengembangkan kesadaran akan tanggung jawab kebersihan lingkungan melalui bimbingan dan penyuluhan.

\section{Kerangka Teori}

\section{a. Konsep Implementasi Kebijakan}

Thoha (2014:101) mengemukakan bahwa konsep public policy masuk dalam ilmu administrasi sudah lama dikenal. Pada awalnya decision-making process. Konsep decision-making process terbatas pada pengembangan konsep kepemimpinan yang menjadi topik bahasan aktual dalam pengembangan ilmu adimistrasi negara. Oleh karena cakupan ilmu administrasi negara substansinya adalah seluas dengan aktifitas negara yang berkaitan dengan kehidupan rakyatnya, maka aktivitas rakyat dalam suatu sistem negara yang demokratis berpengaruh terhadap perkembangan konsep decision-making process dalam ilmu administrasi negara. Pokok perhatian utama administrasi negara saat itu ialah Public Policy. Bidang kajian ini sangat penting bagi administrasi negara, karena selain ia menentukan arah umum yang harus ditempuh untuk mengatasi isu-isu masyarakat, ia pun dapat dipergunkan sebagai ruang lingkup permasalahan yang dihadapi oleh pemerintahan. Selain itu, dapat pula dipergunakan untuk mengetahui betapa luasnya dan besarnya organisasi pemerintahan ini. Pendapat Pasolong (2013:1) juga mengemukakan bahwa administrasi publik dimaksudkan untuk lebih memahami hubungan pemerintah dengan publik serta meningkatkan responsibilitas kebijakan terhadap berbagai kebutuhan publik, dan juga melembagakan praktik-praktik manajerial agar terbiasa melaksanakan suatu kegiatan dengaan efektif, efisien, dan rasional. Adapun ruang ligkup administrasi publik menurut Nicholas Henry (1995) dalam Pasolong (2013:19) adalah sebagai berikut :

1. Organisasi Publik, pada prinsipnya berkenaan dengan model organisasi dan perilaku birokrasi;

2. Manajemen Publik, yaitu berkenaan dengan sistem dan ilmu manajemen, evaaluasi program dan produktivitas, anggaran publik dan manajemen sumber daya manusia; dan

3. Implementasi, yaaitu menyangkut pendekatan terhadap kebijakan publik dan implementasinya, privatisasi, administrasi antar pemerintah dan etika birokrasi.

Budi Winarno (2012:18) “Kebijakan adalah suatu ucapan atau tulisan yang memberikan petunjuk umum tentang penetapan ruang lingkup yang memberikan 
batasan dan arahan umum kepada seseorang untuk bergerak". Secara etimologis, kebijakan adalah terjemaahan dari kata policy. Kebijakan dapat juga berarti sebagai rangkaian konsep dan asas-asas yang menjadi garis pelaksanaan suatu pekerjaan, kepemimpinan, dan cara bertindak. Kebijakan dapat berbentuk keputusan yang dipikirkan secara matang dan hati-hati oleh pengambil keputusan puncak dan bukan kegiatan-kegiatan berulang yang rutin dan terprogram atau terkait dengan aturan-aturan keputusan. Mengenai pengertian kebijakan, banyak para ahli kebijakan yang memberikan pendapatnya masing-masing mengenai istilah kebijakan itu sendiri diantaranya menurut Richad Rose dalam Winarno (2012:20), "kebijakan adalah serangkaian kegiatan yang sedikit banyak berhubungan beserta konsekuensi-konsekuensinya bagi mereka yang bersangkutan dari pada sebagai suatu keputusan tersendiri". Berdasarkan pengertian kebijakan tersebut dapat diambil kesimpulan bahwa di balik suatu kebijakan terdapat konsekuensi dampak baik buruknya atas kebijakan yang dihasilkan terhadap mereka yang bersangkutan dalam pengambilan keputusan kebijakan tersebut.

Menurut Carl Friedrich dalam Budi Winarno (2012:21), "Kebijakan adalah sebagai suatu arah tindakan yang diusulkan oleh seseorang, kelompok atau pemerintah dalam suatu lingkungan tertentu yang memberikan hambatanhambatan dan peluang-peluang terhadap kebijakan yang diusulkan untuk menggunakan dan mengatasi dalam rangka mencapai suatu tujuan atau merealisasikan suatu sasaran atau suatu maksud tertentu". Sedangkan menurut Anderson dalam Budi Winarno (2012:21), kebijakan adalah arah tindakan yang mempunyai maksud yang ditetapkan oleh seorang aktor atau sejumlah aktor dalam mengatasi suatu masalah atau suatu persoalan.

Adapun menurut Kartasasmita dalam Widodo (1991:13), "Kebijakan adalah upaya untuk memahami dan mengerti apa yang dilakukan (atau tidak dilakukan) oleh pemerintah mengenai suatu masalah, apa yang menyebabkan dan mempengaruhinya, dan apa pengaruh dan dampak dari kebijakan publik tersebu". Berdasarkan pengertian tersebut dapat diambil kesimpulan bahwa pemerintah melakukan suatu kebijakan itu karena ada masalah karena ada penyebabnya dan ada yang mempengaruhinya, serta akan ada konsekuensi dari kebijakan tersebut.

Selanjutnya menurut Friedrich dalam Wahab (1991:13) mengatakan bahwa, kebijakan sebagai suatu tindakan yang mengarah pada tujuan yang diusulkan oleh seseorang, kelompok atau pemerintah dalam lingkungan tertentu sehubungan dengan adanya hambatan-hambatan tertentu seraya mencari peluang-peluang untuk mencapai tujuan atau mewujudkan sasaran yang diinginkan. Berdasarkan pengertian tersebut dapat diambil kesimpulan bahwa kebijakan terjadi karena ada usulan dari orang-orang yang terkait dalam pengambilan kebijakan untuk mencapai tujuan yang diinginkan. Tentang pengertian kebijakan publik, banyak para ahli kebijakan yang memberikan pendapatnya masing-masing mengenai istilah kebijakan publik. Menurut Dye dalam Widodo (2007:12) yaitu: “Whatever governments choose to do or not to do" Kebijakan publik adalah apapun yang 
pemerintah pilih untuk melakukan atau tidak melakukan sesuatu. Berdasarkan pengertian tersebut dapat diambil kesimpulan bahwa kebijakan publik adalah hal yang dipilih pemerintah untuk melakukan atau tidak melakukan suatu kebijakan untuk kepentingan banyak orang.

Menurut Wilson dalam Solichin Abdul Wahab (2006:154) yaitu "The action, objectives, and pronouncements of governments on particular matters, the steps they take (or fail to take) to implement them, and the explanations they give for what happens (or does not happen)". Kebijakan publik yaitu tindakan-tindakan, tujuan-tujuan, dan pernyataan-pernyataan pemerintah mengenai masalah-masalah tertentu, langkahlangkah yang telah atau sedang diambil (atau gagal diambil) untuk diimplementasikan, dan penjelasan-penjelasan yang diberikan oleh mereka mengenai apa yang telah terjadi (atau tidak terjadi) diusulkan oleh seseorang, kelompok atau pemerintah dalam lingkungan tertentu sehubungan dengan adanya hambatan-hambatan tertentu seraya mencari peluang-peluang untuk mencapai tujuan atau mewujudkan sasaran yang diinginkan. Berdasarkan pengertian tersebut dapat diambil kesimpulan bahwa kebijakan terjadi karena ada usulan dari orang-orang yang terkait dalam pengambilan kebijakan untuk mencapai tujuan yang diinginkan. Tentang pengertian kebijakan publik, banyak para ahli kebijakan yang memberikan pendapatnya masing-masing mengenai istilah kebijakan publik. Menurut Dye dalam Widodo (2007:12) yaitu: “Whatever governments choose to do or not to do" Kebijakan publik adalah apapun yang pemerintah pilih untuk melakukan atau tidak melakukan sesuatu. Berdasarkan pengertian tersebut dapat diambil kesimpulan bahwa kebijakan publik adalah hal yang dipilih pemerintah untuk melakukan atau tidak melakukan suatu kebijakan untuk kepentingan banyak orang. Menurut Wilson dalam Solichin Abdul Wahab (2006:154) yaitu "The action, objectives, and pronouncements of governments on particular matters, the steps they take (or fail to take) to implement them, and the explanations they give for what happens (or does not happen)". Kebijakan publik yaitu tindakan-tindakan, tujuan-tujuan, dan pernyataan-pernyataan pemerintah mengenai masalah-masalah tertentu, langkah-langkah yang telah atau sedang diambil (atau gagal diambil) untuk diimplementasikan, dan penjelasan-penjelasan yang diberikan oleh mereka mengenai apa yang telah terjadi (atau tidak terjadi). Sedangkan menurut Edward dan Sharkansky dalam Widodo (2007:12) yaitu: "What government say and do, or not to do. It is the goals or purpose of government programs". Kebijakan publik adalah apa yang pemerintah katakan dan dilakukan atau tidak dilakukan. Sedangkan menurut Anderson dalam Islamy (1994:19), kebijakan publik adalah sebagai serangkaian tindakan yang mempunyai tujuan tertentu yang diikuti dan dilaksanakan oleh pelaku atau sekelompok pelaku guna memecahkan masalah tertentu. Dengan memperhatikan definisi kebijakan para ahli di atas nampak bahwa kebijakan itu merupakan sesuatu yang tidak hanya menekankan pada apa yang diusulkan pemerintah, tetapi juga mencakup pula arah tindakan atau apa yang dilakukan oleh pemerintah. Demikian pula kebijakan publik ini dibuat untuk memecahkan masalah dan untuk mencapai tujuan dan sasaran 
tertentu yang diinginkan. Kebijakan publik dibuat bukannya tanpa maksud dan tujuan, maksud dan tujuan kebijakan publik dibuat adalah untuk memecahkan masalah publik yang tumbuh kembang di masyarakat.

\section{b. Konsep Implementasi Kebijakan}

Tentang pengertian implementasi, banyak para ahli kebijakan yang memberikan pendapatnya masing-masing mengenai istilah implementasi menurut Webster dalam Wahab (1991 : 50) yaitu: "to provide the means for carrying out practical effects to (menimbulkan dampak atau akibat terhadap sesuatu)". Implementasi yaitu menyediakan sarana untuk melaksanakan suatu kebijakan dan dapat menimbulkan dampak atau akibat terhadap sesuatu tertentu. Sedangkan menurut Jones dalam Widodo (2007: 86) yaitu: "a process of getting additional resources so as to figure out what is to be done". Implementasi merupakan proses penerimaan sumber daya sehingga dapat menghitung apa yang harus dikerjakan.

Berdasarkan pengertian implementasi di atas bahwa implementasi adalah suatu proses yang melibatkan sejumlah sumber yang termasuk manusia, dana, dan kemampuan organisasional yang dilakukan oleh pemerintah maupun swasta (individu atau kelompok). Nugroho (2008:432) mengemukakan bahwa implementsi kebijakan pada prinsipnya adalah cara agar sebuah kebijakan dapat mencapai tujuannya oleh sebab itu, untuk mengimplementsikan suatu kebijakan ada dua pilihan, yakni langsung mengimplementasikannya dalam bentuk program atau melalui formulasi kebijakan turun (derivat). Grindle (1980:7) mengemukakan bahwa proses implementasi baru akan dimulai apabila tujuan dan sasaran telah ditetapkan, program kegiatan telah tersusun dan telah siap disalurkan utuk mencaapai sasaran.

Dari kedua pendapat di atas nampak bahwa implementasi adalah apa yang telah direncanakan dan tersusun rapih untuk segera direalisasikan dalam bentuk nyata dan bertujuan untuk kesejahteraan bersama serta mampu mencapai hasil yang sesuai dengan harapan atau target kebijakan. Van Meter dan Van Hor dalam Budi Winarno (2005:102) merumuskan implemenntasi kebijakan publik sebagai tindakan-tindakan yang dilakukan oleh badan publik yang diarahkan untuk mencapai tujuan-tujuan yang telah ditetapkan dalam serangkaian keputusan sebelumnya. Tindakan-tindakan ini mencakup usaha-usaha untuk mengubah keputusan-keputusan menjadi tindakan-tindakan operasional dalam kurun waktu tertentu maupun dalam rangka melanjutkan usaha-usaha untuk mencapai perubahan-perubahan besar dan kecil yang ditetapkan oleh keputusankeputusan kebijakan.

Menurut Darwin (1998:54) persiapan proses implementasi yang perlu dilakukan, setidaknya terdapat empat hal penting, yaitu pendayagunaan sumber, pelibatan orang atau sekelompok orang dalam implementasi, interpretasi, 
manajemen program, penyuaian layanan, dan manfaat pada publik. Jones dalam Gaffar (1997) menyatakan bahwa aktivitas implemetasi kebijkan terdapat tiga macam, antara lain sebagai berikut:

1. Aktivitas Pengorganisasian (Organzation), merupakan suatu upaya untuk menetapkan dan menata kemballi sumber daaya (resources), unit-unit (units), dan metode-metode (methods) yang mengarah pada upaya mewujudkan atau merealisasian kebijakan menjadi hasil (outcomme) sesuai dengan apa yang menjadi tujuan dan sasaran kebijakan;

2. Aktivitas Interpretasi (Interpretation), merupakan aktivitas interpretas (penjelasan) substaansi dari suatu kebijakan dalam bahasa yang lebih operasional dan mudah dipahami sehingga dapat dilaksanakan dan diterima oleh para pelaku dan sasaran kebijaakan;

3. Aktivitas Aplikasi (Application), merupakan aktivitas penyediaan pelayanan secara rutin.

Berdasarkan kedua pendapat tersebut maka perlu mendapatkan perhatian dan persiapan dalam proses implementasi kebijakan interpretasi, organisasi, penyediaan risorsis, dan manajemen program, sserta penyediaan layanan dan manfaat pada publik. Atas dasar ini, maka masalah implementasi semakin lebih jelas dan luas. Impementasi itu merupakan proses yang memerlukan tindakantindakan sistematis dari pengorganisasian, interpretasi, dan aplikasi.

\section{a. Model Implementasi Kebijakan Edward III}

Menurut Nugroho (2004:166) bahwa pada prinsipnya terdapat dua pemilihan jenis teknik atau model implementasi kebijakan. Pemilihan pertama adalah implementasi kebijakan yang berpola "dari atas ke bawah" (top-bottomer) dan "dari bawah ke atas" (bottom-topper). Dwiyanto (2009:19) mengemukakan bahwa model adalah sebuah kerangka sederhana yang merupakan sebuah usaha untuk memudahkan penjelasan terhadap suatu fenomena. Menurut Edwards dalam Widodo, (2007:96-110). Untuk dapat mengimplementasikan kebijakan secara sempurna maka diperlukan beberapa persyaratan, antara lain:

1. Faktor Komunikasi (Communication)

Komunikasi diartikan sebagai proses penyampaian impormasi komunikator kepada komunikan. Komunikasi kebijakan berarti merupakan proses penyampaian informasi kebijakan dari pembuat kebijakan (policy maker) kepada pelaksana kebijakan (policy implementors).

Informasi kebijakan publik perlu disampaikan kepada pelaku kebijakan agar para pelaku kebijakan dapat mengetahui, memahami apa yang menjadi isi, tujuan, arah, kelompok sasaran (target grup) kebijakan agar para pelaku kebijakan dapat mempersiapkan dengan benar apa yang harus dipersiapkan dan lakukan untuk melaksanakan kebijakan publik agar apa yang menjadi tujuan dan sasaran kebijakan dapat dicapai dengan yang diharapkan.

2. Sumber Daya (Resources) 
Bahwa faktor sumber daya ini juga mempunyai peranan penting dalam implementasi kebijakan. Bagaimanapun jelas dan konsistennya ketentuanketentuan atau aturan-aturan tersebut, jika para pelaksana kebijakan yang bertanggung jawab untuk melaksanakan kebijakan kurang mempunyai sumber-sumber daya untuk melakukan pekerjaan secara efektif, maka implementasi kebijakan tersebut tidak akan efektif.

3. Disposisi (Disposition)

Keberhasilan implementasi kebijakan bukan hanya ditentukan oleh sejauh mana para pelaku kebijakan (implementers) mengetahui apa yang harus dilakukan dan mampu melakukannya, tetapi juga ditentukan kemauan para pelaku kebijakan tadi memiliki disposisi yang kuat terhadap kebijakan yang sedang diimplementasikan.

Disposisi ini merupakan kemauan, keinginan, dan kecenderungan para pelaku kebijakan untuk melaksanakan kebijakan tadi secara sungguhsungguh sehingga apa yang menjadi tujuan kebijakan dapat diwujudkan.

4. $\quad$ Struktur Birokrasi (Bureaucratic structure)

Meskipun sumber-sumber untuk mengimplementasikan suatu kebijakan cukup dan para pelaksana (implementers) mengetahui ada dan bagaimana cara melakukannya, serta mereka mempunyai keinginan untuk melakukannya. Namun implementasi kebijakan bisa jadi masih belum efektif karena adanya ketidakefisienan struktur birokrasi. Struktur birokrasi ini mencakup aspek-aspek struktur organisasi, pembagian kewenangan, hubungan antara unit-unit organisasi yang ada dalam organisasi yang bersangkutan, dan sebagainya.

Sedangkan menurut Van Meter dan Van Horn dalam buku Budiman Rusli (2013: 105) menetapkan beberapa variabel yang diyakini dapat mempengaruhi implementasi dan kinerja kebijakan yaitu diantaranya:

1. Standar dan Sasaran Kebijakan

Standar dan sasaran kebijakan harus jelas dan terukur, sehingga tidak menimbulkan interpretasi yang dapat menyebabkan terjadinya konflik di antara para agen implementasi.

2. Sumber Daya

Kebijakan perlu didukung oleh sumber daya, baik itu sumber daya manusia maupun sumber daya non manusia. Menunjukan kepada seberapa besar dukungan finansial dan sumber daya manusia untuk melaksanakan program atau kebijakan. Hal sulit yang terjadi adalah berapa nilai sumber daya (baik finansial maupun manusia) untuk menghasilkan implementasi kebijakan dengan kinerja baik. Evaluasi program atau kebijakan seharusnya dapat menjelaskan nilai yang efisien.

3. Komunikasi Antar Badan Pelaksana

Dalam berbagai kasus, implementasi sebuah program terkadang perlu didukung dan dikoordinasikan dengan instansi lain agar tercapai keberhasilan yang diinginkan. Menunjukan kepada mekanisme prosedur 
yang dicanangkan untuk mencapai sasaran dan tujuan program. Komunikasi ini harus ditetapkan sebagai acuan, misalnya: seberapa sering rapat rutin akan diadakan, tempat dan waktu. Komunikasi antar organisasi juga menunjukkan adanya tuntutan saling dukung antar institusi yang berkaitan dengan program atau kebijakan.

4. Karakteristik Badan Pelaksana

Sejauhmana kelompok-kelompok kepentingan memberikan dukungan bagi implementasi kebijakan. Termasuk didalamnya karakteristik para partisipan yakni mendukung atau menolak, kemudian juga bagaimana sifat opini publik yang ada di lingkungan dan apakah elite politik mendukung implementasi kebijakan tersebut dan menunjukkan seberapa besar daya dukung struktur organisasi, nilai-nilai yang berkembang, hubungan dan komunikasi yang terjadi di internal birokrasi.

5. Lingkungan Sosial, Ekonomi, dan Politik

Lingkungan sosial, ekonomi, dan politik mencakup sumber daya ekonomi lingkungan yang dapat mendukung keberhasilan implementasi kebijakan dalam menunjukkan bahwa lingkungan dalam ranah implementasi dapat mempengaruhi kesuksesan implementasi kebijakan itu sendiri.

6. Sikap Pelaksana

Menunjuk bahwa sikap pelaksana menjadi variabel penting dalam implementasi kebijakan. Seberapa besar demokratis, antusias, dan responsif terhadap kelompok sasaran dan lingkungan, beberapa yang dapat ditunjuk sebagai bagian dari sikap pelaksana ini.

\section{Metode Penelitian}

Dalam penelitian ini, penulis menggunakan metode deskriptif kualitatif yaitu data yang dikumpulkan adalah berupa kata-kata, gambar dan bukan angka-angka. Hal itu disebabkan oleh adanya penerapan model kualitatif. Selain itu, semua yang dikumpulkan berkemungkinan menjadi kunci terhadap apa yang efektif. Hal ini sesuai dengan pendapat (Moleong, 2010: 11). Yang menggunakan ciri-ciri metode penelitian sebagai berikut:

1. Memusatkan perhatian pada pemecahan-pemecahan masalah yang ada pada masa sekarang dan masalah-masalah actual;

2. Data yang dikumpulkan mula-mula disusun dan dijelaskan, kemudian dianalisis.

\section{Hasil dan Pembahasan}

\section{a. Kondisi Sosiografis Kecamatan Subang}

Kecamatan Subang terletak di Kabupaten Subang dengan luas wilayah $5,896,966$ ha yang terdiri dari: pesawahan 2,922,920 ha dan darat 2,974,646 ha. 
Kecamatan Subang merupakan kecamatan terpadat di Kabupaten Subang. Kecamatan Subang berbatasan langsung dengan empat Kecamatan di Kabupaten Subang, yaitu sebelah Utara berbatasan dengan Kecamatan Pagaden, sebelah selatan berbatasan dengan Kecamatan Cijambe, sebelah Timur berbatasan dengan Kecamatan Cibogo, serta sebelah Barat berbatasan dengan Kecamatan Dawuan. Kecamatan Subang terdiri atas 8 Kelurahan/Desa, yaitu: Kelurahan Karanganyar; Kelurahan Parung; Kelurahan Pasirkarembi; Kelurahan Sukamelang; Kelurahan Wanareja; Kelurahan Dangdeur; Kelurahan Cigadung; dan Kelurahan Soklat. Penduduk Kecamatan Subang berjumlah 176,140 jiwa, apabila dilihat dari jenis kelamin terdiri dari 78,983 orang laki-laki dan 97,157 orang perempuan. Menurut agama yang dianut penduduk Kecamatan Subang adalah 165,453 orang beragama Islam, 4,987 orang beragama Protestan, 975 orang beragama Katolik, 295 orang beragama Buddha, dan 89 beragama Hindu. Jumlah sarana ibadah yang terdapat di Kecamatan Subang yaitu 265 masjid dan 7 gereja.

Visi Kecamatan Subang adalah Visi Subang SKPD yaitu : Terwujudnya Kecamatan Subang sebagai Kecamatan terdepan dalam pelayanan masyarakat pada tahun 2019. Visi kewilayahannya yaitu : Terwujudnya Kecamatan SUBANG HUDANG (Harmonis, Unggul, Dinamis, Aman, dan Gotong Royong). Sedangkan misi Kecamatan Subang adalah Meningkatkan kualitas tata kelola pemerintahan; Meningkatkan efektifitas koordinasi dan pembinaan; Meningkatkan sinergitas program pembangunan dan pemberdayaan masyarakat berbasis gotong royong' dan Mengakselerasi terwujudnya Kota Adipura

\section{b. Implementasi Kebijakan Ketertiban Kebersihan (K-3) di Kecamatan Subang Kabupaten Subang}

Implementasi Kebijakan Ketertiban Kebersihan (K-3) merupakan program pemerintah dalam meningkatkan Ketertiban, Kebersihan, Keindahan (K-3) di lingkungan masyarakat, karena untuk mencapai masyarakat yang tentram dan sejahtera diperlukan adanya suasana yang tertib, bersih, dan indah. Salah satu masalah terbesar dalam Peraturan Daerah tentang Ketertiban, Kebersihan, Keindahan (K-3) yaitu masalah sampah. (penjelasan k3 masih kurang). Dalam Implementasi Kebijakan Pearaturan daerah tentang Ketertiban, Kebersihan, dan Keindahan (K-3) di Kecematan Subang Kabupaten Subang menurut Van Mater dan Van Horn dalam Budiman Rusli (2013:105) ada 6 Variabel yang mempengaruhi kinerja implementasi kebijakan, yakni:

\section{b.1 Standar dan Sasaran Kebijakan}

Dalam rangka pelaksanaan Program Ketertiban, Kebersihan, Keindahan (K-3) diperlukan standard an sasaran kebijakan yang 
tepat agar Program Ketertiban, Kebersihan, Keindahan (K-3) bisa bejalan sesuai dengan yang diharapkan. Untuk mengefektifkan pelaksanaan program dan pertanggungjawabannya perlu dibentuk tim yang mengkoordinasi di tingkat pusat sampai tingkat terkecil. Implementasi kebijakan Ketertiban, Kebersihan, Keindahan (K-3) adalah kebijakan dari pemerintah, sementara standar kebijakan Ketertiban, Kebersihan, Keindahan (K-3) masih cenderung kurang terealisasikan. Sementara yang menjadi sasaran kebijakan Ketertiban, Kebersihan, Keindahan (K-3) ini yaitu masyarakat masih ada yang tidak mengetahui apa itu K3. Seharusnya masyarakat sadar terutama tentang kebersihannya karena sudah tersedia Tempat Penampungan Sementara (TPS), jadi tidak membuang sampah sembarangan di sepanjang jalan.

Dalam rangka pelaksanaan Program Kebijakan Ketertiban, Kebersihan, Keindahan (K-3) di Kecamatan Subang Kabupaten Subang Perlu dibentuk tim yang mengkoordinasi Kebijakan Ketertiban, Kebersihan, Keindahan (K-3) di tingkat Kecamatan ini, hal ini diharapkan agar implementasi Kebijakan Ketertiban, Kebersihan, Keindahan (K-3) di Kecamatan Subang Kabupaten Subang berjalan dengan maksimal. Berikut hasil wawancara penulis dengan bagian Kasi Trantrib Kecamatan Subang Kabupaten Subang mengenai Standar dan sasaran kebijakan Program Kebijakan Ketertiban, Kebersihan, Keindahan (K-3) di Kecamatan Subang sebagai berikut: SOP nya sudah ada dan sudah sesuai ketentuan, kita tinggal melaksanakan, kalaupun ada kekurangan paling di masyarakat yang belum paham tentang Ketertiban, Kebersihan, Keindahan (K-3) ini. Untuk tujuannya sendiri supaya terciptanya kota Subang yang tertib, bersih, dan indah. Berdasarkan hasil wawancara tersebut pihak Kecamatan sudah melaksanakan Program Kebijakan Ketertiban, Kebersihan, Keindahan (K-3) sesuai dengan aturan yang ditetapkan oleh pemerintah, seperti mengadakan sosialisasi terlebih dahulu jika mau membongkar bangunan liar. Hasil observasi dilapangan masih kurangnya soalisasi dari pihak kecamatan dan masih adanya masyarakat yang belum mengetahui apa itu Program Kebijakan Ketertiban, Kebersihan, Keindahan (K-3).

\section{b.2 Sumber Daya}

Sumber daya adalah faktor penting untuk implementasi kebijakan agar efektif, tanpa sumber daya kebijakan hanya tinggal diatas kertas dan menjadi dokumen saja. Sumber-sumber yang penting meliputi: Masyarakat, staf yang memadai serta keahliankeahlian yang baik untuk melaksanakan tugas-tugas mereka, dan 
sumber daya non manusia. Sumber daya manusia adalah salah satu faktor yang penting bahkan tidak dapat dilepaskan dari sebuah organisasi, baik institusi maupun perusahaan.

Sumber daya manusia juga merupakan kunci yang menentukan perkembangan suatu perusahaan atau suatu organisasi. Pengelolaan sumber daya manusia (SDM) merupakan hal yang penting dalam pencaian tujuan, oleh karena itu kualitas sumber daya manusia (SDM) harus dikembangkan dan diarahkan agar tercapai tujuan yang telah ditetapkan dan diharapkan semua pihak. Begitu pula dalam implementasi Kebijakan Ketertiban, Kebersihan, Keindahan (K-3) diperlukan sumber daya.

Berikut hasil wawancara penulis dengan aparatur Kecamatan Subang Kabupaten Subang mengenai dukungan sumber daya manusia maupun non manusia dalam pelaksanaan Program Kebijakan Ketertiban, Kebersihan, Keindahan (K-3), sebagai berikut: Sumber daya dalam pelaksanaan Program Kebijakan Ketertiban, Kebersihan, Keindahan (K-3) sudah bagus dan sesuai kebijakan, sayangnya yang dijadikan sasaran Kebijakan Program Ketertiban, Kebersihan, Keindahan (K-3) belum begitu mengerti dan memahami seperti masih adanya bangunan liar, masih adanya masyarakat yang mebuang sampah sembarangan, masih adanya pengemis, dan tidak semua warga hadir jika ada gotong royong, misal membersihkan kali dikarenakan berbagai alasan. Untuk anggarannya ada pengurangan dari tahun 2018. Berdasarkan hasil wawancara tersebut diatas peneliti menganalisis bahwa dari kabupaten telah memberikan sop yang baik untuk dilaksanan kecamatan, begitupun pihak kecamatan melakukan sosialisai kepada masyarakat terlebih dahulu jika dapat perintah dari kabupaten untuk masyarakat, walapun, masih adanya masyarakat yang belum mengerti, memahami, dan mengetahui adanya Program Kebijakan Ketertiban, Kebersihan, Keindahan (K3), karenan menurut Van Meter dan Van Horn kebijakan perlu didukung oleh sumber daya, baik sumber daya manusia maupun sumber daya non manusia. Agar Program Kebijakan Ketertiban, Kebersihan, Keindahan (K3) bisa berjalan sesuai dengan apa yang diharapkan. Berikut hasil wawancara dengan salah satu masyarakat Kecamatan Subang Kaupaten Subang, sebagai berikut: Tempat penampungan sementara (TPS) sudah ada, tapi masih adanya masyarakat yang membandel dengan membuang sampah sembarangan. Untuk yang mengurusinya sendiri sudah ada walaupun kadang masih ada sampah yang menumpuk tp selama ini tidak sampai menggunung sampahnya. Hasil observasi dilapangan terkait sumber daya manusia untuk menunjang 
Program Kebijakan Ketertiban, Kebersihan, Keindahan (K-3) ditingkat kecamatan masih belum maksimal hal itu dapat dilihat dari belum adanya petugas yang mengkoordinir sampah dari lingkungan ke Tempat Penampungan Sementara (TPS), hail itu menyebabkan masyarakat membuang sampah dimana saja. Dalam suatu organisasi baik itu institusi maupun perusahaan, jika satu orang tidak respek terhadap yang lain maka semua yang akan menanggung dan merasakan akibatnya. Demikian juga dalam bidang sumber daya manusia ini, masing-masing peran ini adalah esensial terhadap seluruh peran sumber daya manusia. Seringkali organisasi mengutamakan peran tertentu saja dan mengabaikan peran yang lain sehingga dapat mengakibatkan tidak efektifnya fungsi sumber daya manusia.

\section{b.3 Komunikasi Atar Badan Pelaksana}

Program yang dibuat oleh pemerintah dalam usaha menciptakan lingkungan yang tertib, bersih, dan indah adalah dengan adanya Program Ketertiban, Kebersihan, Keindahan (K-3). Masyarakat pada umumnya acuh dalam melihat sampah yang berserakan disepanjang jalan, masyarakat tau dampak buruk membuang sampah sembarangan namun masyarakat kebanyakan acuh akan hal tersebut. Dengan adanya Program Ketertiban, Kebersihan, Keindahan (K-3) di Kecamatan Subang Kabupaten Subang diharapkan program ini dapat memberikan dampak yang baik bagi lingkungan. Keberhasilan implementasi kebijakan mensyaratkan agar implementor mengetahui apa yang harus dilakukan, apa yang menjadi tujuan, dan sasaran kebijakan harus ditransmisikan kepada kelompok sasaran sehingga mengurangi distorsi implementasi. Apa tujuan dan sasaran suatu kebijakan tidak jelas atau bahkan tidak diketahui sama sekali oleh kelompok sasaran, maka kemungkinan akan terjadi resistensi dari kelompok sasaran.

Harus adanya pemahaman yang menyeluruh mengenai kesepakatan terhadap tujuan atau sasaran yang akan dicapai dan yang terpenting keadaan ini harus dapat dipertahankan selama proses implementasi. Tujuan tersebut haruslah dirumuskan dengan jelas, spesifik dan lebih baik apabila dapat dipahami dan disepakati oleh seluruh pihak yang terlibat dalam organisasi, bersifat saling melengkapi dan mendukung serta mampu berperan selaku pedoman dengan demikian pelaksanaan program dapat dimonitor. Harus ada komunikasi dan koordinasi yang sempurna diantara berbagai unsur atau badan yang terlibat dalam program. Dalam hubungan ini bahwa untuk mencapai 
implementasi yang sempurna barang kali harus diperlukan suatu sistem satuan administrasi yang baik. Komunikasi memang memainkan peran penting bagi berlangsungnya koordinasi dan implementasi pada umumnya. Implementasi kebijakan ditentukan oleh isi dan konteks implementasinya. Implementasi Kebijakan tentang Ketertiban, Kebersihan, Keindahan (K3) bertujuan untuk menciptakan lingkungan yang tertib dan indah untuk kenyamanan bersama.

Berikut hasil wawancara penulis dengan bagian Kasi Trantrib Kecamatan Subang Kabupaten Subang mengenai komunikasi antar badan pelaksana dalam pelaksanaan Program Kebijakan Ketertiban, Kebersihan, Keindahan (K3), sebagai berikut: Koordinasi dan kerjasama dalam pelaksanaan Program Kebijakan Ketertiban, Kebersihan, Keindahan (K3) terutama tentang ketertiban sudah ada dari dinas terkait/kabupaten, kita dari kecamatan tinggal menjalan perintah atau intruksinya aja. Untuk sosialisasi kepada masyarakat Kecamatan Subang Kabupaten Subang pun sudah dilakukan. Dari hasil wawacara tersebut menunjukan bahwa Kecamatan Subang hanya menjalan perintah yang diberikan dari dinas terkait/kabupaten, jika ada perintah pihak kecamatanpun langsung koordinasi dengan dinas terkait dan masyarakat. Hasil observasi dilapangan menunjukan bahwa komuniksai dari kabupaten ke kecamatan memang ada, namun untuk warga sendiri tidak semua mengetahui. Berdasarkan hasil penelitian dapat disimpulkan bahwa persyaratan pertama bagi implementasi kebijakan yang efektif yaitu adanya komunikasi, baik komunikasi antar unsur pimpinan Pemerintahan Daerah, Pemerintahan Desa, dan warga masyarakat Kecamatan Subang Kabupaten Subang.

\section{b.4 Karakteristik Agen Pelaksana}

Walaupun isi kebijakan sudah dikomunikasikan secara jelas dan konsisten, tetapi apabila implementor kekurangan sumber daya untuk melaksanakan, implementasi tidak akan berjalan efektif. Sumber daya tersebut dapat berwujud sumberdaya manusia, yakni kompetensi implementor dan sumber daya financial. Sumber daya adalah factor penting untuk implementasi kebijakan agar efektif. Tanpa sumber daya, kebijakan hanya tinggal dikertas menjadi dokumen saja.

Tujuan implementasi kebijakan diformulasi kedalam program aksi dan proyek tertentu yang dirancang dan dibiayai oleh pemerintah. Implementasi kebijakan atau program secara garis besar dipengaruhi oleh isi kebijakan dan konteks implementasi. 
Keseluruhan Implementasi kebijakan dievaluasi dengan cara mengukur keluaran program berdasarkan tujuan kebijakan. Keluaran program dilihat melalui dampaknya terhadap sasaran yang dituju, baik individu dan kelompok maupun masyarakat. Keluaran implementasi kebijakan adalah perubahan dan diterimanya perubahan oleh kelompok sasaran. Dalam melaksanakan kebijakan Ketertiban, Kebersihan, Keindahan (K-3) agar tercapai dengan baik, maka harus disusun dalam urutan yang tepat seluruh tugas yang harus dilaksanakan oleh setiap pihak yang terlibat dalam pelaksanaan implementasi kebijakan Peraturan daerah tentang Ketertiban, Kebersihan, Keindahan (K-3) di Kecamatan Subang Kabupaten Subang. Tingkat komitmen dan keterampilan dari aparat implementor, pada akhirnya komitmen aparat pelaksana untuk merealisasikan tujuan yang telah tertuang dalam kebijakan adalah variabel yang paling krusial. Aparat badan pelaksana harus memiliki keterampilan dalam membuat prioritas tujuan dan selanjutnya merealisasikan prioritas tujuan tersebut. Birokrasi merupakan salah satu badan yang paling sering bahkan secara keseluruhan menjadi pelaksana kebijakan. Birokrasi secara sadar atau tidak sadar memilih bentuk-bentuk organisasi untuk kesepakatan kolektif, dalam rangka memecahkan masalahmasalah sosial dalam kehidupan modern. Berikut hasil wawancara penulis dengan bagian Kasi Trantrib Kecamatan Subang Kabupaten Subang mengenai karakteristik badan pelaksana dalam pelaksanaan Program Kebijakan Ketertiban, Kebersihan, Keindahan (K-3), sebagai berikut: Pokoknya kami hanya menjalankan sesuai dengan SOP nya itu sendiri dan dengan petunjuk teknis dari pusat. Dari pemerintah daerah/Kabupaten tidak ada yang turun langsung kelapangan untuk memberikan penyuluhan kepada masyarakat, hanya memberitahu sebagian aparat Kecamatan yang bertugas di bidangnya. Berdasarkan hasil wawancara diatas bahwa memang yang seharusnya turun langsung kelapangan untuk memberikan penyuluhan atau sosialisasi kepada masyarakat adalah dari pihak Kecamatan dan pihak Desa. Namun jika dari pihak kabupaten turun langsung kelapanganpun tidak apa-apa, karena menurut Van Mater dan Van Horn dalam suatu kebijakan konsistensi sikap implementor dari tingkat pimpinan puncak sampai pelaksana harus memberikan dukungan agar implementasi kebijakan bisa berjalan dengan baik. Konsistensi sikap implementor dari tingkat pimpinan puncak sampai pelaksana untuk mengimplementasikan kebijakan sesuai dengan tujuan kebijakan yang telah ditentukan. Di yakini bahwa dengan adanya konsistensi sikap implementor 
dari mulai proses perencanaan sampai dengan proses pengawasan akan sangat memberikan kontribusi terhadap keberhasilan Implementasi Kebijakan Peraturan Daerah tentang Ketertiban, Kebersihan, Keindahan (K-3) di Kecamatan Subang Kabupaten Subang.

\section{b.5 Lingkungan Sosial, Ekonomi, dan Politik}

Kemiskinan dan kesehatan akan memberikan masalah sosial yang lainnya seperti tindakan kejahatan, buruknya kondisi lingkungan, disinilah diperlukan suatu tindakan upaya yang berarti dan tepat untuk mengatasi masalah ini. Salah satunya dengan membuka lapangan kerja yang baru dan menciptakan suasana yang tertib, bersih, dan indah. Salah satu program yang dibuat oleh pemerintah dalam usaha meningkatkan kenyamanan, keamanan, dan kesehatan adalah dengan dilaksanakannya Program Ketertiban, Kebersihan, dan Keindahan (K-3). Masyarakat pada umumnya banyak yang tidak mengetahui tentang Program Ketertiban, Kebersihan, dan Keindahan (K-3) dan masih banyak pula masyarakat yang acuh dengan bahaya membuang sampah dimana saja terhadap kesehatan dan lingkungan. Berikut hasil wawancara penulis dengan bagian Kasi Trantrib Kecamatan Subang Kabupaten Subang mengenai lingkungan sosial, ekonomi, dan politik dalam pelaksanaan Program Kebijakan Ketertiban, Kebersihan, Keindahan (K-3), sebagai berikut: Sangat mempengaruhi, karena jika tanpa dukungan lingkungan sosial misal sulit untuk tercapainya subang yang tertib, bersih, dan indah. Berdasarkan hasil wawancara diatas bahwa banyak faktor yang dapat mempengaruhi Kebijakan tentang Ketertiban, Kebersihan, Keindahan (K-3) diantaranya lingkungan sosial, ekonomi, dan politik. Tanpa memiliki dukungan lingkungan sosial, ekonomi, dan politik Program Ketertiban, Kebersihan, Keindahan (K-3) tidak akan berjalan maksimal. Karena menurut Van Meter dan Van Horn dalam suatu kebijakan agar dapat berjalan dengan baik harus ada dukungan lingkungan sosial, ekonomi, dan politik yang baik untuk keberhasilan program yang diharapkan. Berikut hasil wawancara penulis dengan masyarakat Kecamatan Subang Kabupaten Subang mengenai lingkungan sosial, ekonomi, dan politik dalam pelaksanaan Program Kebijakan Ketertiban, Kebersihan, Keindahan (K-3), sebagai berikut: Jika ada ajakan untuk bergotong royong kebanyakan masyarakat menyetujui ajakan tersebut, karena sebagaian masyarakat sadar/peduli ada dampak baik dengan bergotong royong seperti dengan bekerja bakti 
membersihkan sampah otomatis akan terlihat bersih dan enak dipandang serta terhindar dari berbagai penyakit yang diakibatkan dari sampah yang menumpuk. Berdasarkan hasil wawancara diatas bahwa pernyataan tersebut menguatkan pernyataan dari informan sebelumnya, yang mengatakan Program Ketertiban, Kebersihan, Keindahan (K-3) akan bejalan dengan baik apabila memiliki dukungan lingkungan sosial, ekonomi, dan politik terutama dari masyarakat. Hasil observasi dilapangan menunjukan bahwa lingkungan sosial, ekonomi, dan politik sangat mempengaruhi keadaan lingkungan, hal itu dapat dilihat dari keadaan lingkungan yang kurang memberikan kenyamanan masalah kebersihannya yang dapat mengganggu kesehatan dan tidak enak dilihat. Pemerintah sebagai pelaku kebijakan publik, perlu sekali memperhatikan tuntutan masyarakat dalam proses politik sesuai dengan asas demokrasi pancasila. Dengan demikian bukan hasil yang baik saja yang menjadi jangkauan kebijakan, akan tetapi juga proses kegiatan-kegiatan untuk tercapainya tujuan itu perlu mendapat perhatian dalam mempersiapkannya. Dimock mengatakan bahwa di dalam masyarakat yang merdeka, maka kepentingan-kepentingan yang tidak melanggar hokum adalah bebas bersaing untuk maju, sedangkan tugas utama dari pemerintah adalah membantu pihak yang satu dan lainnya atau memadukan diantara kepentingan-kepentingan itu, semua di dasararkan pada terciptanya kepentingan masyarakat, yaitu meningkatkan ketertiban dan keamanan, kemantapan kehidupan ekonomi dan kemajuan rakyat (Soekarno, 2003:100).

\section{b.6 Sikap Pelaksana}

Apabila pelaksana memiliki sikap yang baik, maka dia akan menjalankan kebijakan dengan baik seperti apa yang diinginkan oleh pembuat kebijakan. Ketika implementor memiliki sikap atau perpektif yang berbeda dengan pembuat kebijakan, maka proses implementasi kebijkan juga menjadi tidak efektif. Implementasi kebijakan adalah pelaksanaan keputusan dasar, biasanya dalam bentuk undang-undang, namun dapat pula berbentuk perintahperintah atau keputusan-keputusan yang penting. Lazimnya keputusan tersebut mengidentifikasikan masalah yang ingin diatasi, menyebutkan secara tegas tujuan atau sasaran yang ingin dicapai, dan berbagai cara untuk menstrukturkan atau mengatur proses implementasinya. Proses ini berlangsung setelah melalui sejumlah tahapan tertentu, kemudian output kebijakan dalam bentuk pelaksanaan keputusan oleh badan pelaksan, kesediaan dilaksanakannya keputusan tersebut oleh kelompok sasaran, 
dampak nyata, dampak keputusan dipersiapkan oleh badanbadan yang mengambil keputusan dan akhirnya perbaikanperbaikan penting terhadap keputusan tersebut. (Mazmanian dan Sabatier dalam Widodo, 2010:193). Berikut hasil wawancara penulis dengan bagian Kasi Trantrib Kecamatan Subang Kabupaten Subang mengenai sikap pelaksana dalam pelaksanaan Program Kebijakan Ketertiban, Kebersihan, Keindahan (K-3), sebagai berikut: Bagus karena Program Ketertiban, Kebersihan, Keindahan (K-3) ini bertujuan unntuk terciptanya kota Subang yang tertib, bersih, dan indah. Baik, dari pihak Dinas/Kabupaten selalu mengkoordinasi kepada kita sebelum terjun langsung ke lapangan dan kita pun siap melaksanakan apa yang diperintahkan sesuai sop yang berlaku. Berdasarkan hasil wawancara diatas bahwa pihak dari dinas selalu berkoordinasi dengan kita Kecamatan Subang Kabupaten Subang bagian Kasi Trantib dan pihak Kecamatan Subang Kabupaten Subang bagian Kasi Trantib pun berhak memutuskan agar Program Kebijakan Ketertiban, Kebersihan, Keindahan (K-3) bisa berjalan maksimal. Hal tersebut tidak lepas dari dukungan masyarakat sekitar, karena menurut Van Mater dan Van Horn kebijakan dapat berjalan dengan baik bilamana implementasi mimiliki sikap pelaksana yang baik maka akan menjalankan kebijakan dengan baik seperti yang diinginkan oleh pembuat kebijakan. Berikut hasil wawancara penulis dengan Masyarakat Kecamatan Subang Kabupaten Subang mengenai sikap pelaksana dalam pelaksanaan Program Kebijakan Ketertiban, Kebersihan, Keindahan (K-3), sebagai berikut: Baik, karena Program Ketertiban, Kebersihan, Keindahan (K-3) ini bertujuan unntuk terciptanya kota Subang yang tertib, bersih, dan indah, dan selalu ada sosialisasi dulu jika ada kegiatan apapun, agar wargapun bisa mengetahui adanya kegiatan tersebut. Berdasarkan hasil wawancara diatas bahwa pihak Kecamatan Subang Kabupaten Subang selalu ada sosialisasi terlebih dahulu kepada masyarakat jika ada kegiatan atau pembongkaran bangunan liar kepada yang punya bangunan tersebut. Hasil observasi dilapangan menunjukan bahwa masih kurangnya pihak kecamatan melakuan sosialisasi tentang Program Kebijakan Ketertiban, Kebersihan, Keindahan (K-3) ini, hal ini dapat dilihat dari masyarakat Kecamatan Subang Kabupaten Subang yang masih adanya yang belum mengetahui apa itu (K-3). Jadi implementasi merupakan pelaksanaan kebijakan dasar, biasanya dalam bentuk undang-undang, namun dapat pula berbentuk perintah-perintah atau keputusan-keputusan yang paling penting atau keputusan badan peradilan. Keputusan tersebut dibuat untuk 
mengatasi permasalahan yang terjadi. Sehingga apabila telah melalui suatu proses akan dihasilkan suatu output kebijakan dan akan diketahui dampak nyata dan dampak keputusan tersebut bagi kelompok sasaran, itu terlihat dalam pelaksanaan Kebijakan Ketertiban, Kebersihan, Keindahan (K-3) di Kecamatan Subang Kabupaten Subang.

\section{Kesimpulan}

Berdasarkan hasil penelitian yang penulis lakukan mengenai Implementasi Kebijakan Ketertiban, Kebersihan, Keindahan (K-3) di Kecamatan Subang Kabupaten Subang, maka penulis merumuskan kesimpulan sebagai berikut:

1. Standar dan sasaran kebijakan

Standar sasaran kebijakan Program Ketertiban, Kebersihan, Keindahan (K-3) adalah program dari pemerintah, program ini dilaksanakan dari atas ke bawah (top down) karena dalam proses implementasi peran pemerintah sangat besar. Pada pendekatan ini yang terjadi adalah para pembuat keputusan merupakan aktor kunci dalam keberhasilan implementasi, karena untuk menciptakan suasana yang tertib, bersih, dan indah salah satunya dengan adanya Program Ketertiban, Kebersihan, Keindahan (K-3).

2. Sumber daya

Dalam proses Implementasi Kebijakan Program Ketertiban, Kebersihan, Keindahan (K-3) dukungan sumberdaya sangat mendukung, yaitu sumberdaya manusia dan sumberdaya non manusia, dan dalam sumberdaya manusianya sendiri yaitu masyarakat Kecamatan Subang Kabupaten Subang.

3. Komunikasi antar badan pelaksana

Pelaksanaan komunikasi dalam proses Implementasi Kebijakan Program Ketertiban, Kebersihan, Keindahan (K-3) di Kecamatan Subang Kabupaten Subang sudah berjalan cukup baik, hal ini dapat dilihat dari dinas terkait apabila ada kegiatan selalu koordinasi kepada pihak Kecamatan Subang Kabupaten Subang.

4. Karakteristik badan pelaksana Aparatur Kecamatan Subang Kabupaten Subang sudah melaksanakan Program Ketertiban, Kebersihan, Keindahan (K-3) cukup baik, konsistensi sikap implementor dari tingkat pimpinan puncak sampai pelaksana untuk mengimplementasikan kebijakan sesuai dengan tujuan yang telah ditentuka, hanya saja belum maksimal pelaksanaannya dilapangan.

5. Lingkungan sosial, ekonomi, dan politik

Lingkungan sosial, ekonomi, dan politik akan berdampak kemiskinan dan kesehatan, karena buruknya lingkungan sosial, ekonomi dan politik akan 
berdampak pada buruknya lingkungan yang dapat merusak Ketertiban, Kebersihan, Keindahan (K-3).

6. Sikap pelaksana

Kasi trantib telah melaksanakan Ketertiban, Kebersihan, Keindahan (K-3) dengan baik, hanya saja masih ada kekurangan dilapangan seperti masih kurangnya penyuluhan yang mengakibatkan masih adanaya masyarakat yang tidak mengetahui Ketertiban, Kebersihan, Keindahan (K-3).

\section{Referensi}

Abdul Wahab, Solichin. (2017). Analisis Kebijakan, dari formulasi ke penyusunan modelmodel Implementasi Kebijakan Publik. Jakarta : Bumi Aksara.

Dunn, William N. (1988). Pengantar Kebijakan Publik, ahli bahasa drs.Samudra Wibawa dkk. Yogyakarta : Gajah Mada Univercity Pres.

Dwijowijoto, Riant Nugroho. (2004). Kebijakan Publik : Formulasi, Implementasi, dan Evaluasi. Jakarta : Elex Media Komputindo.

Indiahono, Dwiyanto. (2009). Kebijakan Publik Berbasis Dynamic Policy Analisys. Yogyakarta : Gava Media.

Islamy, M Irfan. (1984). Kebijakan Negara (prinsip-prinsip perumusan). Jakarta : Bumi Aksara.

Mulyadi, Deddy. (2015). Studi Kebijakan Publik dan Pelayanan Publik, konsep dan aplikasi proses kebijakan publik dan pelayanan publik. Bandung : Alfabeta.

Moleong, Lexy. (2010). Metodologi Penelitian Kualitatif. PT RemajaRosdakarya. Bandung.

Nugroho, Riant. (2004). Kebijakan Publik Formulasi, Implementasi dan Evaluasi. Gramedia. Jakarta.

Pasolong, Harbani. (2013). Teori Administrasi Publik. Bandung : Alfbeta.

Peraturan Daerah Kabupaten Subang Nomor : 13 tahun 2006 tentang Ketertiban, Kebersihan, dan Keindahan di Wilayah Kabupaten Subang

Rusli, Budiman. (2013). Kebijakan Publik: Membangun Pelayanan Publik Yang Responsif. Bandung : Hakim Publishing.

Sugiono. (2013). Metode Penelitian Administrasi, dilengkapi dengan metode $R \mathcal{E} D$. Bandung : Alfabeta. 


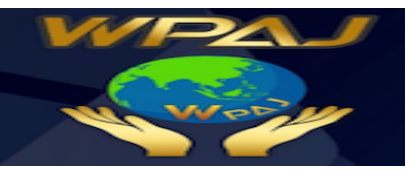

Volume 1 Issue 1, Juni 2019

https:// ejournal.unsub.ac.id/index.php/publik

Suradinata, Ermaya. (1994). Teori dan Praktek Kebijakan Negara. Bandung : Ramadhan.

Thoha. Miftah. (2014). Ilmu Administrasi Publik Kontemporer. Jakarta : Kencana.

Widodo, Joko. (2007). Analisis Kebijakan Publik. Malang : Bayumedia.

Wilson, Graham. (1993). Problem Solving and Decession - Making (pemecahan masalah dan pengambilan keputusan) Peterjemahan Domino Q Roosmin dkk. Jakarta : PT Gramedia.

Winarno, Budi. (2012). Kebijakan Publik Teori, Proses dan Studi Kasus. Yogyakarta : CAPS. 